\title{
Water Budget of a Shallow Aquifer in the Lower Coastal Plain: ACE Basin, SC
}

\author{
Rachael L.A. Kassabian ${ }^{1}$, Timothy J. Callahan ${ }^{2}$, and Saundra Upchurch ${ }^{3}$
}

\begin{abstract}
AUTHORS: ' 'University of Charleston, South Carolina, 66 George Street, Charleston, SC 29424, USA. ${ }^{2}$ Director, Graduate
Program in Environmental Studies and Associate Professor of Geology and Environmental Geosciences, University of

Charleston, South Carolina and College of Charleston, 66 George Street, Charleston, SC 29424, USA. ${ }^{3}$ Biologist, South

Carolina Department of Natural Resources, 217 Fort Johnson Road, Charleston, SC 29422.
\end{abstract}

\begin{abstract}
The expansive tidal salt marshes of South Carolina support a unique and sensitive ecosystem providing environmental and economic value to the coastal community. These tidal ecosystems are often altered by sea level rise through various processes, including the lesser-known stress of saltwater intrusion in groundwater systems. The goal of this research was to measure the baseline groundwater dynamics of an undeveloped tidal saltmarsh. Groundwater wells were installed along transects from the upland into the marsh and a culminating water budget of the watershed was developed. Analysis of water table dynamics showed that in the upland zone, evapotranspiration and precipitation were the dominant processes, whereas in the marsh zone and the uplands directly adjacent to the marsh, water table fluctuations were dominated by tides. An influencing feature for the site was the large tidal creek (Big Bay Creek), which is a tributary of the South Edisto River. The cut bank of Big Bay Creek was adjacent to the south end of the study site where tidal influence on the shallow groundwater was observed. The location of an ephemeral stream through the site was considered as a potential pathway for saltwater intrusion into the uplands, yet this was not confirmed. Groundwater response rates were likely influenced by the presence of fine-grained, well-drained sandy soils. Application of this research will assist coastal resource managers identifying pathways of marsh migration as driven by future seal level rise.
\end{abstract}

\section{INTRODUCTION}

Salt marshes support a collection of unique and sensitive ecosystems providing environmental and economic value to the coastal community. Storm protection, carbon sequestration, nutrient transformation, and fisheries support are a few of the benefits provided by healthy tidal salt marshes (Kirwan and Megonigal, 2013). However, their ecological viability may be threatened by sea level rise and land-use stressors such as coastal development. Furthermore, saltwater intrusion resulting from sea level rise may disrupt the hydrologic balance between the salt marsh and fresh upland groundwater system.
An area of primary significance in this study was the interaction between the marsh transition unit (MTU) and upland systems. The MTU is significant because it is the initial area available for landward marsh movement during erosional processes, such as sea level rise (Doar, 2011). The dynamics driving MTU's, such as salinization, elevation, and tidal inundation help determine the capability of landward marsh mobility (Gardner et al., 2002). A study at North Inlet, SC by Gardner et al. (2002) found that the upland border of the marsh was already transforming into available marsh space from increases in salinity and tidal fluctuations. The same study points out a gap in knowledge about the groundwater flow dynamics that occur along the MTU, particularly along areas of differing elevation gradients (Gardner et al., 2002). In this study at Edisto Beach, $\mathrm{SC}$, groundwater monitoring methods aimed to expand knowledge on the groundwater dynamics occurring across the uplands and MTU.

Furthermore, this research analyzed the baseline groundwater dynamics of an undeveloped tidal saltmarsh at Edisto Beach State Park, SC an Ashepoo, Combahee, and Edisto (ACE) Basin National Estuarine Research Reserve System (NERRS) site. This site location is significant because it represents a relatively undeveloped soft-coast saltmarsh and upland system. This study site reflects ecological dynamics that occur on natural, undisturbed salt marshes similar to this one.

\section{PROJECT DESCRIPTION}

The groundwater system studied at this site was the surficial aquifer within the South Carolina Lower Coastal Plain region. This aquifer is unconfined so it is mainly subjected to infiltration of precipitation and areal recharge, as well as atmospheric pressure effects (SC DNR, 2009). Due to this exposure of the surficial aquifer to the surface, anthropogenic land-use practices are a defining threat to this groundwater system. Although a majority of groundwater systems contain fresh water, surficial aquifers in close proximity to tidal systems may contain saltwater (SC DNR, 2009). This study 
focused on the area of marsh known as the MTU, which is similar to the high marsh, classified as only being flooded during very high tides twice a month from new and full moon phases (NOAA Ocean Service Education, 2008). Additionally, this study spotlighted the upland maritime forest bordering the marsh. In order to understand the relationship of groundwater movement between the marshupland zone, groundwater monitoring wells were installed in a triangulated network. The use of groundwater monitoring wells in the maritime forest and MTU zone allowed for data collection of various groundwater variables over an 11-month time period to highlight the monthly and seasonal dynamics, as well as to capture storm events. The primary objective of this research was to calculate the water budget for the watershed, which illustrated the influence of the surficial aquifer on the upland and marsh interface.

Additionally, the main goal of this study was to describe the groundwater dynamics that occur in the surficial aquifer at this marsh-upland interface. In order to satisfy this goal, the relationships among topography, potential evapotranspiration, precipitation, tidal amplitude and duration were identified. It was hypothesized that groundwater dynamics would mimic the topography of the watershed and salinity would decrease with increasing distance from the saltwater source, Big Bay Creek. Furthermore, the water budget in the upland zone of this coastal site of a maritime forest and adjacent tidal salt marsh should be dominated by water demand for evapotranspiration and precipitation, whereas in the marsh zone, tidal forcing should control the water budget.

\section{METHODS}

\section{Study Area}

The study site for this project is located in a maritime forest and adjacent undeveloped tidal saltmarsh along Big Bay Creek at Edisto Beach State Park within the ACE Basin, South Carolina. The marsh bordering Big Bay Creek is tidally dominated and the vegetation along the marsh study zone is characterized by Spartina alterniflora, Salicornia virginica (glasswort), and Juncus roemerianus. The upland portion of the study site is proximal to the marsh, and the topographic relief of the uplands to the marsh is about 2.5 $\mathrm{m}$. The upland flora is consistent with a southern maritime forest. The maritime forest at this location is classified as a near-coast forest whose plant community is influenced by salt spray and typically is characterized by live oak, cabbage palmetto, Southern magnolia, red bay, yaupon, American holly, sparkleberry, wax myrtle, and saw palmetto (Whitaker et al., 2009). A distinguishing physical feature at this site is an ephemeral stream running perpendicular to Big Bay Creek.

The depth of the shallow surficial aquifer being studied at the site ranges from approximately a meter below mean sea level (BMSL) to 15 meters BMSL (Park, 1985). Beneath the surficial aquifer lies the Cooper Formation from 15 to 115 meters BMSL and the Santee Limestone/Floridan Aquifer from 107 to 189 meters BMSL (Park, 1985).

\section{Field Study Collection}

Wells were installed in a triangular pattern to determine the direction of groundwater movement and hydraulic gradient. Three wells were located in the uplands (North, Middle, and South) and three in the MTU (T5, T2 Shallow, and T2 Deep) (Figure 1). The T2 wells were coupled at varying depths in order to indicate whether there was a difference in groundwater readings based on the depth or the presence of a freshwater lens. Each of the wells consists of a solid PVC pipe connected to a screened PVC pipe to allow groundwater to flow through the bottom of the well. A bentonite seal was applied above the well screen to guarantee water was being monitored from the screen depth and not infiltrating from the surface. The well depths were dependent on the depth of the water table at each of the sites to guarantee a continuous groundwater supply in the wells. The varying lengths of the wells and screen depths are displayed in Table 1. Solinst levelogger instruments were deployed in each well using braided fishing line measured as string length (Table 1). The Solinst levelogger instruments allowed for 30-minute data collection of water temperature (C), electrical conductivity $(\mu \mathrm{S} / \mathrm{cm})$, water level $(\mathrm{cm})$, and barometric pressure $(\mathrm{kPa})$ from June 6, 2013 to May 5, 2014. For the purposes of this study, all electrical conductivity readings were converted to salinity (ppt) and groundwater data were compensated for pressure and temperature.

Mapping the topography of the study site was important to delineate the watershed and also to understand the

\section{Groundwater Monitoring Well Sites in the ACE Basin NERRS}

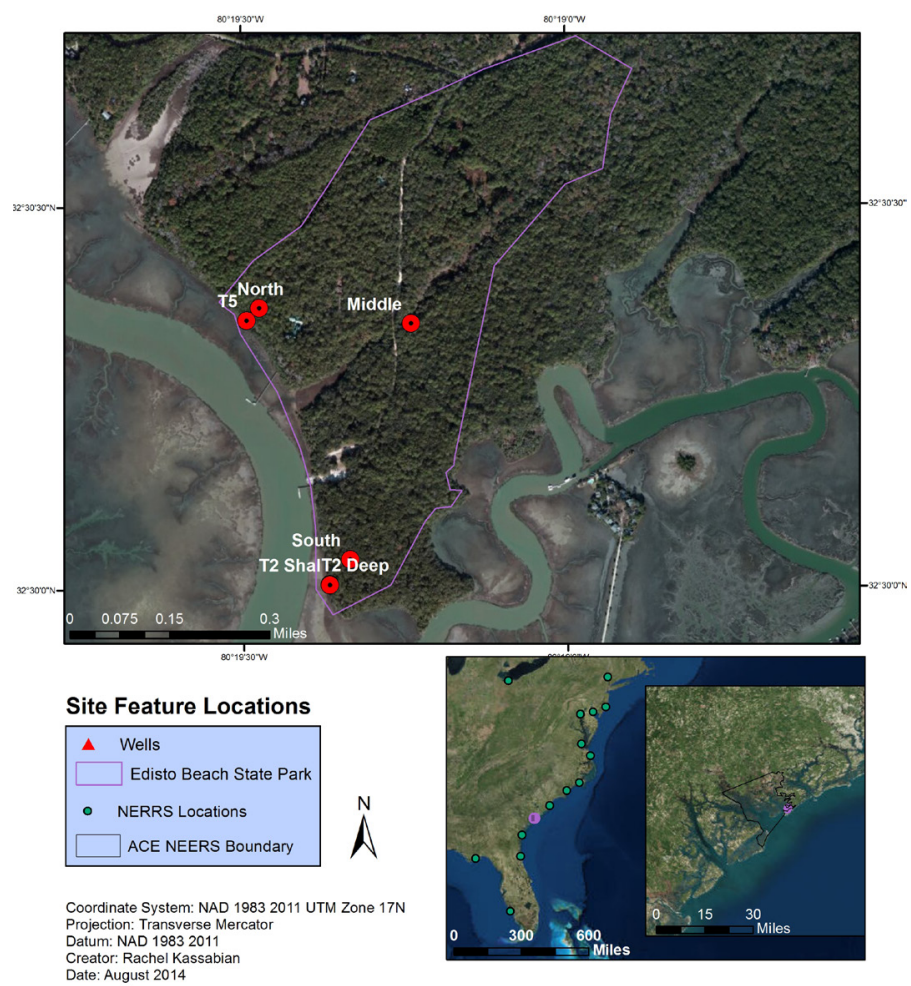

Figure 1. Site Map including NERRS Boundaries and well locations. 
relationship between groundwater levels in the wells to relative elevation (AMSL). In order to determine the upland and marsh elevation for the well sites, traditional surveying was performed using an RTK Global Positioning System (GPS). By relating the elevation of ground surface of each well to height above mean sea level (AMSL), the water levels were established and related by use of a common datum at each well site. The watershed was delineated using ArcGIS from a digital elevation map constructed from LIDAR. The ground elevations and coordinates of each of the wells AMSL are displayed in Table 2.

Following the Solinst Levelogger Series User GuideVersion 4, water level inside each well (A) was calculated by the equation:

$$
A=L-B
$$

where $(\mathrm{A})=$ actual water column height; $(\mathrm{B})=$ Barometric pressure; $(\mathrm{L})=$ levelogger total pressure reading. Water level readings were also temperature compensated using in-situ readings (Solinst, 2013).

In order to observe potential tidal influences from adjacent Big Bay Creek, water level and salinity data were retrieved from the NERRS CDMO. Additionally, soil characterization at each well site was also determined

Table 1. Well Installation Depths. "Bgs" stands for below ground surface.

\begin{tabular}{|c|c|c|c|c|c|c|c|}
\hline $\begin{array}{l}\text { Well } \\
\text { ID }\end{array}$ & $\begin{array}{l}\text { Total } \\
\text { Well } \\
\text { Depth } \\
\text { (m) }\end{array}$ & $\begin{array}{l}\text { Top of } \\
\text { Casing } \\
\text { (TOC) } \\
\text { (m) }\end{array}$ & 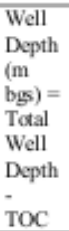 & $\begin{array}{l}\text { Screen } \\
\text { Interval } \\
\text { (m) }\end{array}$ & $\begin{array}{l}\text { Well } \\
\text { Diameter } \\
(\mathrm{m})\end{array}$ & $\begin{array}{l}\text { String } \\
\text { Length } \\
\text { (m) }\end{array}$ & $\begin{array}{l}\text { Water } \\
\text { Table } \\
\text { Depth } \\
\text { (m) }\end{array}$ \\
\hline North & 3.99 & 0.26 & 3.73 & 3.05 & 0.038 & 3.51 & -2.42 \\
\hline Middle & 2.76 & 0.34 & 2.42 & 1.52 & $\begin{array}{l}0.038 \\
\text { (risery } \\
0.032 \\
\text { (screen) }\end{array}$ & 2.59 & -2.36 \\
\hline South & 4.66 & 0.29 & 4.35 & 3.05 & 0.038 & 4.63 & -1.75 \\
\hline T2S. & 1.63 & 0.61 & 1.02 & 0.46 & 0.051 & 1.46 & -0.40 \\
\hline T2D. & 2.80 & 1.10 & 1.70 & 0.30 & 0.051 & 2.68 & -0.38 \\
\hline T5 & 1.75 & 0.62 & 1.13 & 0.46 & 0.061 & 1.65 & -0.23 \\
\hline
\end{tabular}

Table 2. Elevation in meters above mean sea level (AMSL) for ground surface at each well location.

\begin{tabular}{|l|l|l|}
\hline Well Sites & $\begin{array}{l}\text { Elevation } \\
\text { AMSL (m) }\end{array}$ & GPS Coordinates \\
\hline North & 10.37 & $\begin{array}{l}80^{\circ} 19^{\prime} 28.452^{\prime \prime} \mathrm{W}, \\
32^{\circ} 30^{\prime} 22.032^{\prime \prime} \mathrm{N}\end{array}$ \\
\hline Middle & 7.61 & $\begin{array}{l}80^{\circ} 19^{\prime} 14.412^{\prime \prime} \mathrm{W}, \\
32^{\circ} 30^{\prime} 20.772^{\prime \prime} \mathrm{N}\end{array}$ \\
\hline South & 10.71 & $80^{\circ} 19^{\prime} 20.172^{\prime \prime} \mathrm{W}$, \\
& & $32^{\circ} 30^{\prime} 2.268^{\prime \prime} \mathrm{N}$ \\
\hline T2 & 2.60 & $80^{\circ} 19^{\prime} 22.08^{\prime \prime} \mathrm{W}$, \\
Shallow & & $32^{\circ} 30^{\prime} 0.289^{\prime \prime} \mathrm{N}$ \\
\hline T2 Deep & 2.60 & $80^{\circ} 19^{\prime} 22.08^{\prime \prime} \mathrm{W}$ \\
& & $32^{\circ} 30^{\prime} 0.324^{\prime \prime} \mathrm{N}$ \\
\hline T5 & 3.90 & $80^{\circ} 19^{\prime} 29.64^{\prime \prime} \mathrm{W}$, \\
& & $32^{\circ} 30^{\prime} 21.06^{\prime \prime} \mathrm{N}$ \\
\hline
\end{tabular}

during well installation by grab samples every half-meter. Determining the soils and topography helped uncover the groundwater pathways within the watershed.

Additionally, vegetation surveys were carried out in order to more thoroughly analyze the type of vegetation affecting evapotranspiration conditions and to determine basal area. Monitoring basal area determines how much of an area is made up of tree stems (Walsh, 2010). The basal area per tree was summed for each site to determine the total basal area per well location. In order to carry out the basal area study, a $200 \mathrm{~m}$ diameter was plotted around each well and specimens were characterized at circumference breast height $(\mathrm{CBH})$ and then converted to diameter breast height (DBH) by genus and species. The vegetation was broadly grouped by oak trees, pine trees, holly trees, dwarf palmetto, sabal palm, black gum, bald cypress, green ash, and red bay. The equation for determining basal area is:

$$
\text { Basal area per tree }(s q . f t)=0.005454 *(D B H)^{2}
$$

where 0.005454 converts inches into square feet and is called the "forester's constant"; and DBH is equal to diameter at breast height per tree (Mississippi Wildlife, Fisheries \& Parks, n.d.).

\section{Weather Data Collection}

In order to calculate the water budget, precipitation and air temperature data were retrieved from a nearby weather station at Bennett's Point, SC through the NERRS Centralized Data Management Office (CDMO) and converted into total daily readings. The Bennett's Point weather station is located in an open field allowing for the collection of total precipitation with no threat to loss of rainfall from the tree canopy. However, because the Edisto well site is located in a forested upland, throughfall at this site is less than Bennett's Point due to greater interception rates.

Throughfall was calculated for the dominant vegetation types: Eastern hardwood forests (Oak trees) and Southern pine forests (Loblolly Pines) to determine the amount of precipitation reaching the forest floor and the uncertainty of the total precipitation data. The throughfall equation for the Eastern hardwood forests during the growing season is:

$$
T h=0.901(P)-0.031(n)
$$

where Th is throughfall (in); $\mathrm{P}$ is total precipitation (in); and $\mathrm{n}$ is number of storms (Helvey and Patric, 1965). The equation used for the Southern pine forests for Loblolly Pine is (Roth and Chang, 1981):

$$
T h=0.930(P)-0.0011(P)^{2} 0.610
$$

The throughfall results were converted to millimeters and compared to the total precipitation amount. Precipitation compensated for throughfall of the Eastern hardwood forests was used for the calculation of the water budget.

Potential evapotranspiration (PET) was calculated using the Hamon model and an adjusted Hargreaves-Samani (H-S) model. In order to achieve a more accurate PET based on available weather inputs, an averaged PET of the two models 
was used in the water budget calculation. The Hamon model for potential evapotranspiration is:

$$
P E T=0.1651 * L d * R H O S A T * K P E C
$$

where PET is equal to zero when temperature is less than zero; Ld is the daytime length ( $\mathrm{x} / 12$ hours); RHOSAT is the saturated vapor density; and KPEC is the calibration coefficient, which is 1.2 as determined from studies of the southeast United States (Lu et al., 2005).

Dai et al., 2013 successfully used an adjusted HargreavesSamani equation for their study at the Santee Experimental Forest in South Carolina by adding a coefficient to the original $\mathrm{H}-\mathrm{S}$ equation (0.408) to convert extraterrestrial radiation from megajoules/ sq. m./ day into water evaporation depth at $\mathrm{mm} /$ day. An additional coefficient of 0.0021 was used in the coastal North Carolina region (Amatya et al., 2000). The adjusted H-S model supported by Dai et al. (2013) and Amatya et al. (2000) used is:

$$
P E T=0.408 * 0.0021 * R a * T D 0.50 *(T+17.8)
$$

where PET equals daily PET in $\mathrm{mm} /$ day; $\mathrm{T}$ equals daily mean air temperature $\left({ }^{\circ} \mathrm{C}\right)$; Ra equals extraterrestrial solar radiation in MJ. m-2. day-1; TD equals the daily difference between maximum and minimum air temperature $(\mathrm{oC})$.

\section{Water Budget Calculation}

In order to effectively characterize the groundwater flow in this system, a water budget must be determined. A water budget characterizes the inputs and outputs of water flow over a system. Water budgets are useful tools in identifying key pathways that water infiltrates, flows, and exits through a study site. The water budget is a measurement of the processes of the hydrologic cycle, which include precipitation, evapotranspiration, groundwater infiltration, and surface runoff (SC DNR, 2009). In this study, precipitation, groundwater inflow/outflow and evapotranspiration were included in water budget calculations. Runoff was not a factor due to the lack of impervious surfaces and flood inducing storms, as well as highly-permeable soils at the site. The water budget was calculated for over weekly and monthly timescales using the formula:

$$
\triangle S=P-P E T+\triangle G
$$

where $\Delta \mathrm{S}$ is change in storage, $\mathrm{P}$ is precipitation, $\mathrm{PET}$ is potential evapotranspiration, and $\Delta \mathrm{G}$ is change in groundwater. Runoff was not included in this calculation due to the presence of sandy soils at this site and the lack of flood-inducing storms and impervious surfaces.

The change in groundwater $(\Delta \mathrm{G})$ was calculated on a monthly timescale by obtaining daily 1:00 am readings for each well and subtracting the water table depth at the end of the month by the beginning of the month. The change in groundwater depth was additionally normalized for specific yield of the soil and sediments, that is, the available pore space for infiltrating water to fill. Specific yield was
Table 3. Storm events used to calculate specific yield (Sy). WT: water table depth below ground.

\begin{tabular}{|l|l|l|l|}
\hline Events & Precip $(\mathrm{mm})$ & $\Delta \mathrm{WT}(\mathrm{mm})$ & $\mathrm{S}_{\mathrm{y}}$ \\
\hline $6 / 10 / 2013$ & 16.6 & 156 & 0.11 \\
\hline $6 / 19 / 2013$ & 27.1 & 188 & 0.14 \\
\hline $8 / 14 / 2013$ & 56.4 & 751 & 0.08 \\
\hline $11 / 2 / 2013$ & 25.9 & 187 & 0.14 \\
\hline $12 / 14 / 2013$ & 18.8 & 141 & 0.13 \\
\hline Average & & & $\mathbf{0 . 1 2}$ \\
\hline
\end{tabular}

determined from five storm events that caused a rapid rise in water table depth (Table 3). Precursor conditions for these storm events included: (A) water level depth below ground surface could not be greater than $100 \mathrm{~cm}$; and (B) a precipitation event larger than $15 \mathrm{~mm}$ caused the water level change. Specific yield (Sy) was calculated as:

$$
S y=P / \Delta W T
$$

where $\mathrm{P}$ is the total amount from a precipitation event $(\mathrm{mm})$, and $\Delta \mathrm{WT}$ is the change in water table depth $(\mathrm{mm})$ subsequent to the precipitation event (Harder et al., 2007). The average specific yield was calculated from the five events and then multiplied by the change in water table depth to get the resulting change in groundwater $(\Delta \mathrm{G})$ that was used to complete the water budget.

In order to understand the flow of groundwater across the site, Darcy's Law was used to estimate groundwater flux for the upland area. The one-dimensional form of Darcy's Law is:

$$
q=K(\Delta h / \Delta L)
$$

where $\mathrm{q}(\mathrm{m} /$ day) is groundwater flux, $\mathrm{K}$ is hydraulic conductivity $(\mathrm{m} /$ day $), \Delta \mathrm{h}(\mathrm{m})$ is the difference in head between sites, and $\Delta \mathrm{L}(\mathrm{m})$ is the well separation distance (Fitts, 2013).

Hydraulic conductivity was estimated from the typical values of hydraulic conductivity based on sediment type from Davis (1969) and Freeze and Cherry (1979). The highest (103 m/day) and lowest (10-1 m/day) values for hydraulic conductivity for sandy soils were used to capture the range of possible conditions at this site. The $\Delta \mathrm{h}(\mathrm{m})$ also included both the highest and the lowest difference in head values between the north and middle upland wells, and also the same ranges between the south and middle upland wells in order to approximate groundwater flux toward the ephemeral stream channel where the middle well was located.

\section{RESULTS}

\section{Groundwater Dynamics Per Well}

The groundwater hydrograph analysis and water budget results showed that groundwater position over time was affected by both direct and indirect influences. Evapotranspiration, precipitation, and semidiurnal tidal 


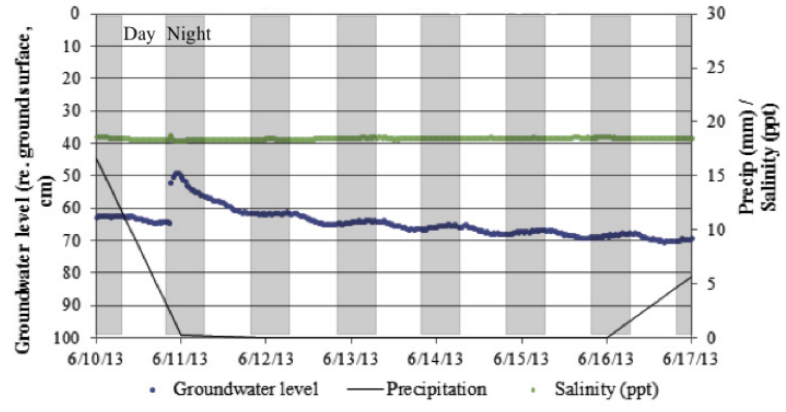

Figure 2. Groundwater and atmospheric dynamics over a 7-day period for the Middle Well. Night is shown as the dark vertical bars. Evapotranspiration-driven groundwater drawdown occurred during the day while groundwater recovery occurred at night.

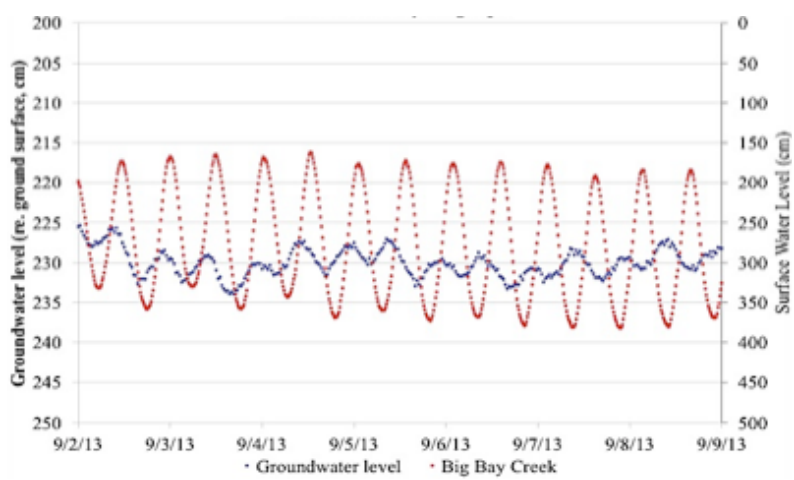

Figure 3. Groundwater dynamics at the South Well compared to Big Bay Creek surface water level over a 7-day period.

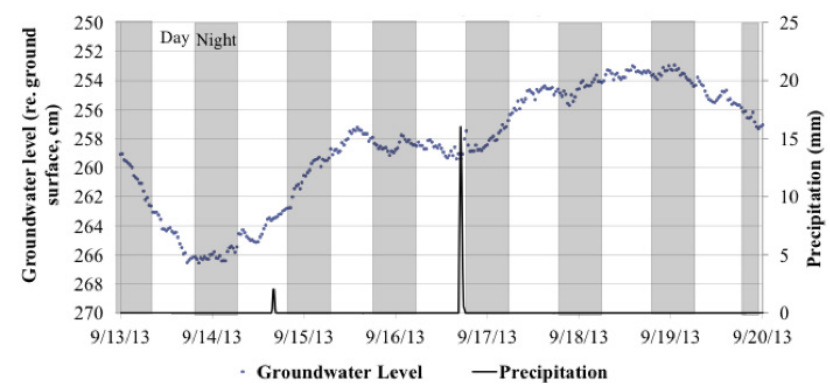

Figure 4. Groundwater and atmospheric dynamics at the North Well occurring over a 7-day period. Nighttimes are the dark bars. Evapotranspiration-driven groundwater drawdown occurs during the day while groundwater recovery occurs at night.

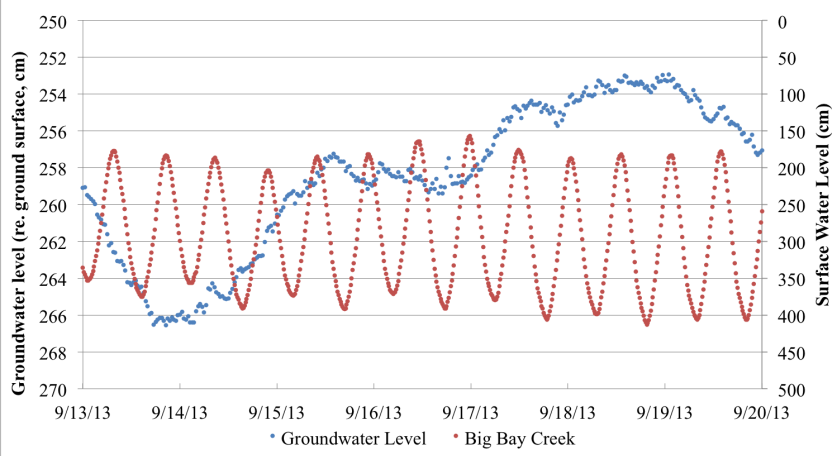

Figure 5. Groundwater dynamics in the North Well compared to Big Bay Creek surface water level over a 7-day period.

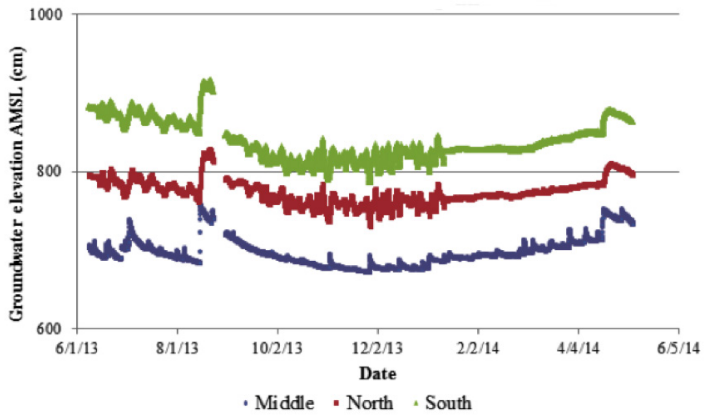

Figure 6. Water table comparison among the three upland wells referenced to AMSL.

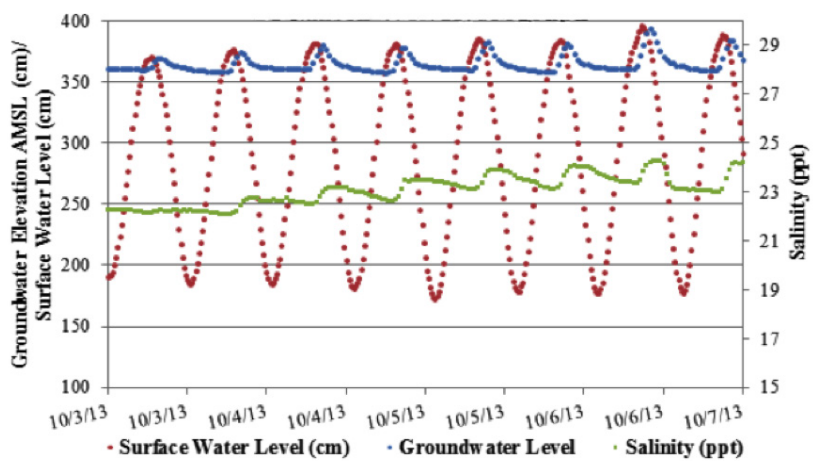

Figure 7. Close-up of T5 groundwater and salinity dynamics compared to Big Bay Creek surface water.

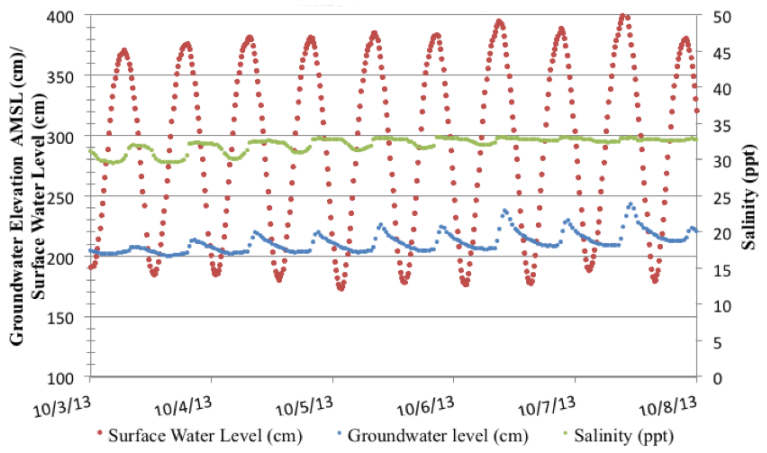

Figure 8. Close-up of T2 Shallow groundwater signature and salinity compared to Big Bay Creek surface water.

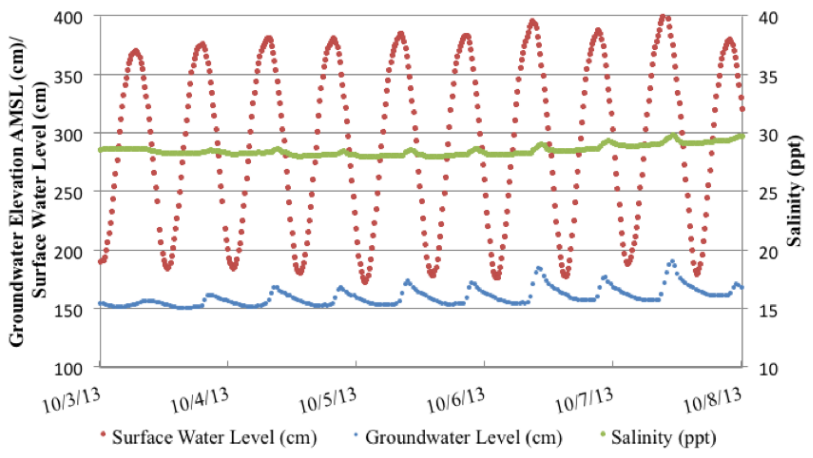

Figure 9. Close-up of T2 Deep groundwater signature and salinity compared to Big Bay Creek surface water. 
signals directly influenced the upland groundwater wells, whereas lunar phases, topography, and seasonal variations in the tides indirectly influenced the groundwater. The main freshwater input to the aquifer for the three upland wells was precipitation-driven infiltration. Over monthly and seasonal timescales, groundwater dynamics were indirectly influenced by lunar phases and landscape position showing recharge under high elevation well sites and discharge at lower elevation sites. In particular, the middle well was the most sensitive to precipitation inputs and diurnal evapotranspiration outputs at a daily rate at the ephemeral stream (Figure 2). The south well was clearly influenced by a delayed tidal signature in the uplands (Figure 3), while the north well lacked a clear evapotranspiration or tidal signature over short term daily analyses (Figure 4 and Figure 5). Groundwater depth in the middle well occasionally reached close to the surface but generally remained around $70 \mathrm{~cm}$ below the surface. The middle well also had the most dynamic groundwater flux, whereas the north and south well remained about $150 \mathrm{~cm}$ to $300 \mathrm{~cm}$ below the ground surface.

The upland groundwater data were converted from depth below ground to mean sea level to enable a comparison of water-level dynamics amongst the three wells. The results of the upland well comparisons showed that all three wells followed the same general long-term trend (Figure 6). The middle well deviated from the north and south wells by responding more dramatically to rain events and lacking an obvious tidal signal. The south, north, and middle wells differed in groundwater depth in that order from deepest to shallowest. The average groundwater elevation for the south well was $843 \mathrm{~cm}$, north well was $776 \mathrm{~cm}$, and middle well was $730 \mathrm{~cm}$.

The MTU wells were mainly influenced by tidal signals and to a lesser extent by precipitation and evapotranspiration, as evidenced by increased salinity readings in the fall and winter months when precipitation rates were low. In particular, the T5 well located in the northern marsh was primarily influenced by semidiurnal tidal patterns although there was a slight lag (1.0 to 1.5 hours) in groundwater highs and lows compared to the surface water of Big Bay Creek (Figure 7). Groundwater patterns at the T2 Shallow and T2 Deep coupled wells, located in the southern marsh, both were dominated by semidiurnal tidal patterns (Figure 8 and Figure 9). The groundwater highs and lows for the coupled wells occurred nearly simultaneously to those in the surface water.

Water levels in the T5 well generally remained at about $15 \mathrm{~cm}$ below ground, but frequently rose above ground due to high tides and rain events. Water levels in the T2 Shallow and Deep wells were generally $35 \mathrm{~cm}$ and $85 \mathrm{~cm}$ below ground, respectively. Water levels in the T2 Shallow well infrequently rose above the surface, whereas the levels in the T2 Deep groundwater never did. The groundwater level in the deep well was typically $50 \mathrm{~cm}$ below that of the shallow well. This difference in groundwater depth reflects a positive (downward) hydraulic gradient between the shallow and deep T2 MTU wells, which is partly due to the greater length of the deeper well and the lower depth of its screen below ground.

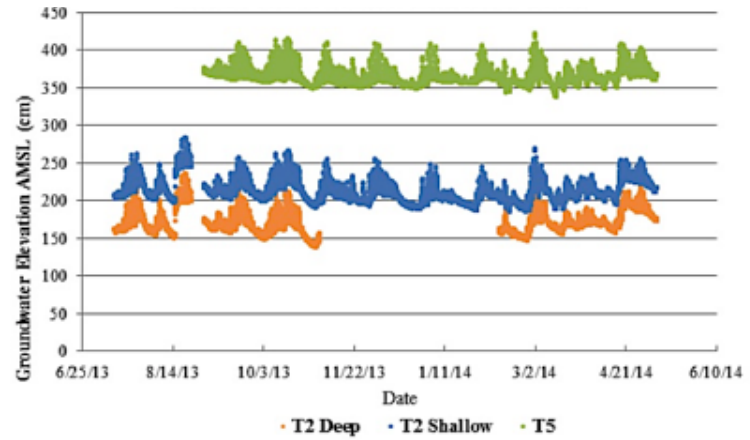

Figure 10. Water table comparison among the three upland wells referenced to AMSL.

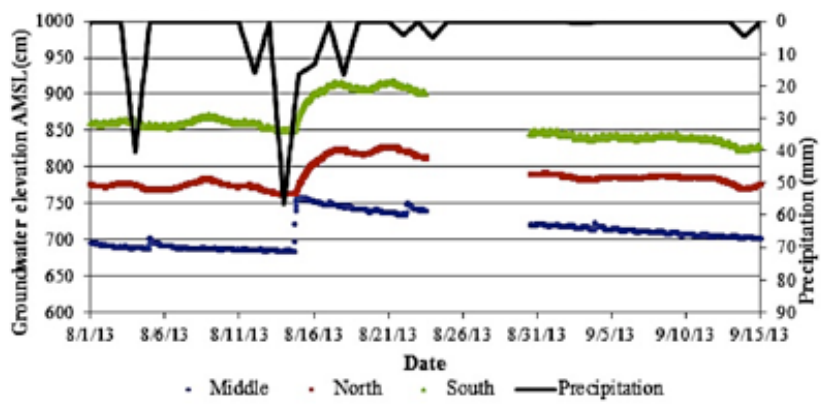

Figure 11. Upland well groundwater levels (AMSL) and precipitation for August 14, 2013 rain event.

The water table elevation graph for the MTU wells referenced to AMSL, showed that all three marsh wells tend to follow the same tidal-driven groundwater pattern (Figure 10). T2 Deep and T2 Shallow were closer in water table elevation. During the first half of the study period, the water table patterns between T2 Deep and T2 Shallow were similar, showing more dramatic gains and losses compared to T5. However, during the second half of the study, during the spring and summer months, all three marsh wells showed clear water table gain and loss patterns.

\section{Rain Event Response}

Precipitation in the upland wells was a clear groundwater input factor, as evidenced by the August 14, 2013 rain event accumulating $56.4 \mathrm{~mm}$ of precipitation (Figure 11). A snapshot of this rain event showed that the middle well rise in groundwater level occurred the same day that the rain event transpired, rising twice as fast in comparison to the other two wells over the same 90-minute period. The north and south wells showed a less dramatic increase in groundwater level during this rain event coming to a peak two days after the initial storm. All three wells then showed a gradual decline in the water table level indicating groundwater infiltration after the rain event. The ground elevations relative to sea level for the south, north, and middle are $1,071,1,037 \mathrm{~cm}$, and $761 \mathrm{~cm}$, respectively.

A closer look at the groundwater response in the marsh wells during and following rain events can be seen in Figures 12 and 13. Figure 12 shows the response of the T2 deep and T2 shallow wells to the August 14, 2013 rain event (the T5 well did 


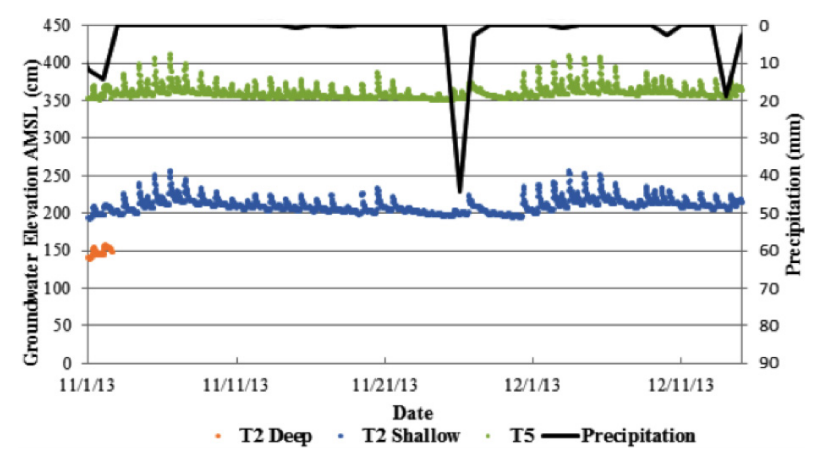

Figure 12. Marsh well groundwater conditions and precipitation for August 14, 2013 rain event.

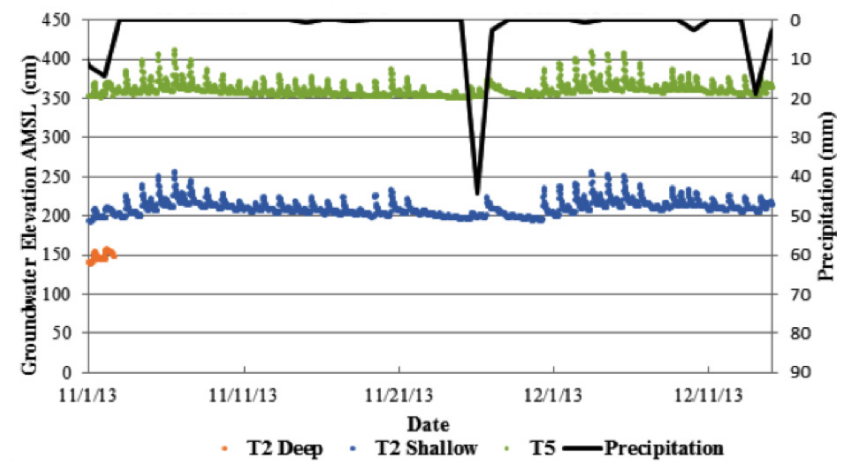

Figure 13. Marsh well groundwater conditions and precipitation for November 26, 2014 rain event. T2 data were not available.

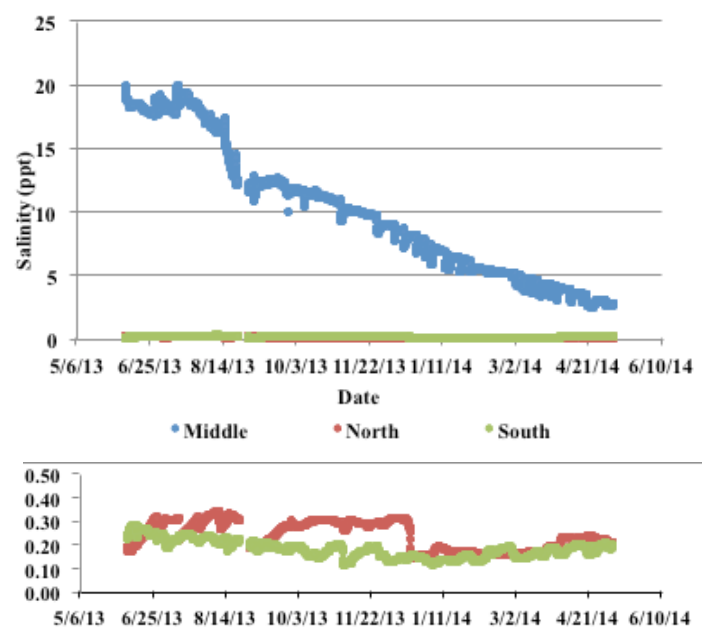

Figure 14. Salinity (ppt) of the three upland wells.

not have a functioning datalogger during this time period). The T2 Shallow and Deep water levels increased by about $40 \mathrm{~cm}$ over a five and six hour period while continuing to show a tidal signal. The ground surface elevations above sea level for the well locations were $390 \mathrm{~cm}$ (T5) and $260 \mathrm{~cm}$ (T2 deep and shallow).

An additional rain event of $44.4 \mathrm{~mm}$ on November 26, 2013 highlights the response of T5 to rain events (Figure 13). This rain event showed that a general tidal signal was present

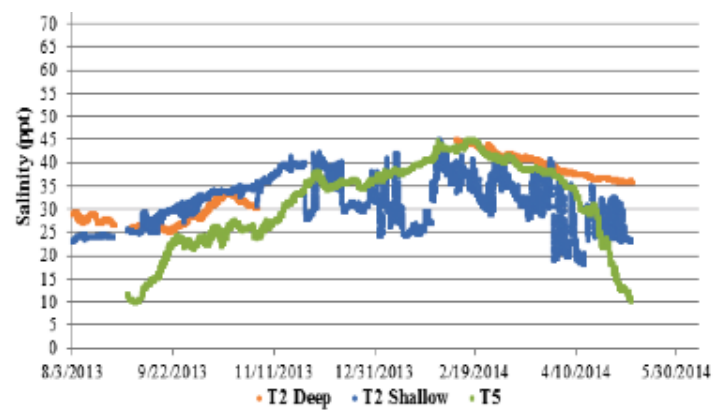

Figure 15. Salinity (ppt) of the three marsh wells.

for both T5 and T2-shallow wells until the rain event signal was diminished. The gain in groundwater level from this rain event was $22 \mathrm{~cm}$ in an 11 hour period for T2 shallow and 13 $\mathrm{cm}$ over an 8.5 hour period for T5. At this time period, the T2 Deep well did not have a functioning datalogger.

\section{Salinity Variations}

Although it was hypothesized that salinity would decrease with increasing distance from the creek, the upland salinity graph shows that this may not be the only contributing factor (Figure 14). In fact, the middle well had the highest salinity level at 30x greater than the north and south wells, although it was the furthest from Big Bay Creek. The middle well salinity was brackish in the earlier time of the study period. The north and south upland wells were considered freshwater groundwater systems since they were within the $0-0.5 \mathrm{ppt}$ salinity range. The salinity for the north and south wells also showed different patterns, particularly evident during the time periods of mid-October 2013 to February 2014.

The salinity variations in the marsh wells were relatively similar to each other (Figure 15). Both T5 and T2 shallow had similar increasing patterns although they were on opposite ends of the study site. This may be due to their comparable well depths. The salinity of the T2 deep well was more stable and could be due to the fact that the well was slightly deeper. The T2 shallow well had a salinity pattern that mimics the tidal signal seen in the groundwater level at this site. It is also clear that compared to the upland wells, the marsh wells' salinity changed seasonally. The summer and spring months showed a generally lower salinity than the fall and winter months.

\section{Main Input/Output Trends}

Precipitation and PET were considered the main input and output factors affecting the water budget at this site. In general, precipitation was the greatest in the summer months (June-August) at $434 \mathrm{~mm}$ and lowest in the winter (DecemberFebruary) at $85.5 \mathrm{~mm}$. The seasonal precipitation pattern was typical of the South Carolina coastal areas (SC DNR, 2009).

In order to generate more accurate results for precipitation to use in the water budget model, throughfall was calculated for the dominant vegetation types: Eastern hardwoods and Southern pines (Figure 16). Throughfall was calculated 
using the total precipitation for the study period $(892.7 \mathrm{~mm})$. Throughfall totals were calculated for the Eastern hardwood $(734.24 \mathrm{~mm})$ and Southern pine forests $(696.46 \mathrm{~mm})$. The amount of precipitation that reached the forest floor, as calculated by throughfall, was $82.25 \%$ for hardwoods during the growing season and $78.02 \%$ for loblolly pine trees. Therefore, about $18 \%$ and $22 \%$ of total precipitation was intercepted by tree canopies for the Eastern hardwood and Southern pine forest types. The total precipitation was adjusted using monthly throughfall rates from the Eastern Hardwood Forest and was used in the water budget calculation to provide accurate site-specific results. It was apparent that the greatest difference between the original and adjusted precipitation occurred in the summer months (June - August) (Figure 16).

The Hamon model and adjusted Hargreaves-Samani model for PET were averaged on a daily and monthly scale to more accurately represent PET rates over the study period (Figure 17). This averaged PET was used as the PET input for the water budget calculation. Potential evapotranspiration comparisons showed that it generally followed the precipitation pattern: greatest rates were found in spring and summer and the lowest in the fall and winter (Figure 17). This pattern coincides with the hottest and coolest months of the years, as well as the growing and dormant vegetation periods, respectively. During the late spring and summer (June to September), potential evapotranspiration averaged about $126 \mathrm{~mm} /$ month then decreased in the fall and winter, eventually reaching the lowest PET value in January ( $34 \mathrm{~mm} / \mathrm{month})$. Evidence for the impact of evapotranspiration was seen in the diurnal groundwater level fluctuations in which the water table decreases during the afternoon due to peak drawdown and then rises to the surface at night or the early morning (Figure 2).

\section{Water Budget}

Precipitation corrected for throughfall, monthly averaged potential evapotranspiration, and groundwater storage $(\Delta \mathrm{G})$ were used to calculate the water budget $(\mathrm{mm})$ on a monthly basis. The overall results of the water budget showed a water deficit, specifically from June to July, September to October, and January to March (Figure 18). Periods of balanced water storage conditions occurred during August, November, and December. April was the only month that had a water surplus for all well locations. The greatest change occurred in April when all six wells experienced a $70 \mathrm{~mm}$ increase in water storage (Table 4). The month of July 2013 is not representative of completed monthly results for the T2 deep and shallow wells which started recording water level on July 12. Additionally, due to datalogger malfunctions, the water budget could not be calculated for the T2 Deep location from November 2, 2013 February 9, 2014.

Overall, the north and south wells maintained similar monthly changes in water storage. The middle well varied monthly with storage changes sometimes comparable to the upland (north and south) or marsh wells. The T2 wells had similar monthly changes in water storage throughout the entire study period and the T5 well only varied slightly from the T2 wells in storage change.

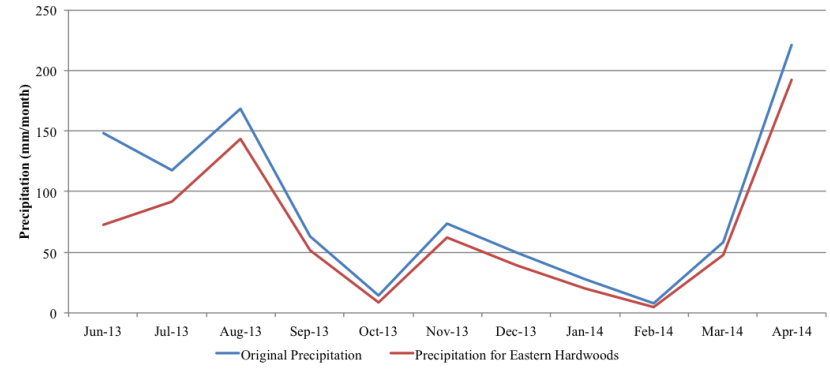

Figure 16. Comparison of original open-field total precipitation (blue) with throughfall using the Eastern Hardwood Forest calculation (red).

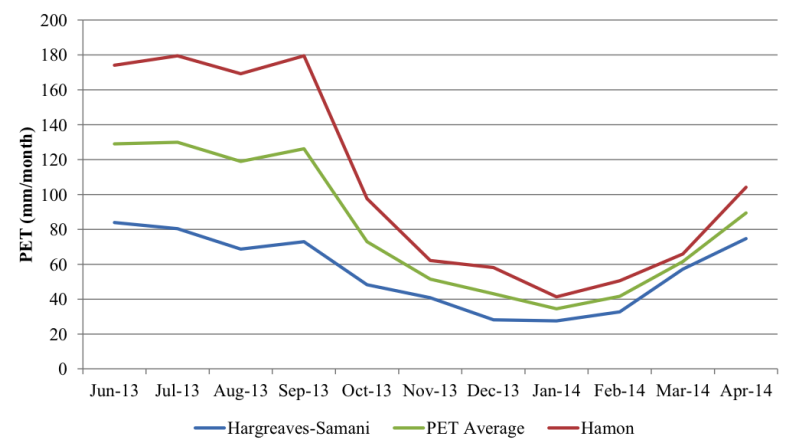

Figure 17. Comparison of the Hamon, adjusted Hargreaves-Samani, and averaged PET calculation used in the water budget calculation.

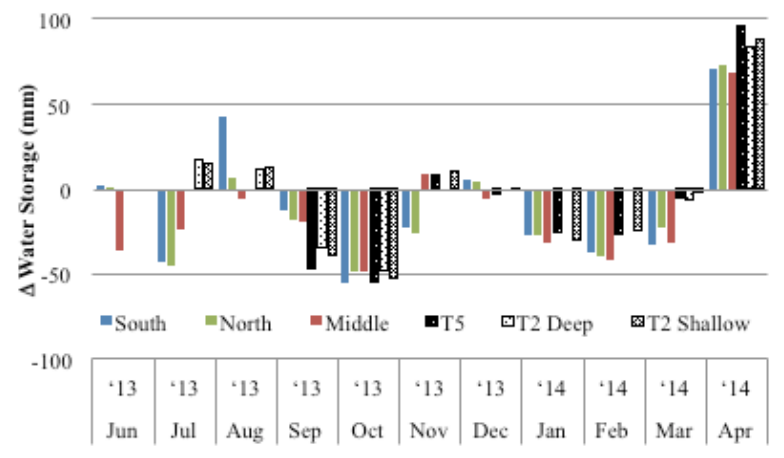

Figure 18. Overall water surplus (positive values) or deficit (negative values) measured at a monthly scale.

A monthly water budget of the middle well was chosen to represent the water storage along a groundwater discharge zone. (Figure 19). The groundwater table was close to the surface at this site and during a precipitation event, groundwater discharge and infiltration directly contributed to the change in water storage. During periods where the groundwater showed a water surplus, this may have indicated ponding at this discharge zone (Figure 19). In April there was a precipitation event, which caused a water surplus at the middle well. Based on the water deficit period over the preceding months, the antecedent water level was low and the large amount of precipitation in April caused the water to rise near the surface indicating the rapid response of groundwater level to water inputs (Figure 19). 
Table 4. Monthly surplus(+)/deficit(-) in mm. N/A: wells not yet installed.

\begin{tabular}{|c|c|c|c|c|c|c|c|c|c|c|c|}
\hline Date & \begin{tabular}{|l|}
$J u n$ \\
$' 13$ \\
\end{tabular} & \begin{tabular}{|l|} 
Jul \\
$\cdot 13$ \\
\end{tabular} & \begin{tabular}{|l|} 
Aug \\
613 \\
\end{tabular} & \begin{tabular}{|l|} 
Sep \\
'13 \\
\end{tabular} & \begin{tabular}{|l|} 
Oct \\
'13 \\
\end{tabular} & \begin{tabular}{|l|} 
Nov \\
'13 \\
\end{tabular} & \begin{tabular}{|l|} 
Dec \\
'13 \\
\end{tabular} & \begin{tabular}{|l|} 
Jan \\
$\cdot 14$ \\
\end{tabular} & \begin{tabular}{|l|} 
Feb \\
$' 14$ \\
\end{tabular} & \begin{tabular}{|l|} 
Mar \\
$\cdot 14$ \\
\end{tabular} & \begin{tabular}{|l|} 
Apr \\
'14
\end{tabular} \\
\hline $\begin{array}{l}\text { South } \\
\Delta \text { Storage }\end{array}$ & 1.60 & -43.53 & 42.58 & -12.61 & -54.99 & -23.29 & 5.50 & -26.96 & -37.02 & -32.77 & 71.09 \\
\hline $\begin{array}{l}\text { North } \\
\Delta \text { Storage }\end{array}$ & 1.40 & -45.77 & 6.86 & -18.38 & -48.65 & -25.92 & 4.13 & -27.53 & -39.34 & -22.79 & 73.32 \\
\hline $\begin{array}{l}\text { Middle } \\
\text { AStorage }\end{array}$ & -36.46 & -23.45 & -6.19 & -19.12 & -48.33 & 8.59 & -6.07 & -31.96 & -42.24 & -31.64 & 68.06 \\
\hline \begin{tabular}{|l} 
T5 \\
$\Delta$ Storage
\end{tabular} & N/A & N/A & N/A & -46.76 & -55.27 & 8.11 & -3.20 & -25.03 & -26.44 & -5.12 & 96.36 \\
\hline $\begin{array}{l}\text { T2 Deep } \\
\Delta \text { Storage }\end{array}$ & N/A & 16.86 & 11.10 & -34.18 & -48.57 & N/A & N/A & N/A & N/A & -6.78 & 83.12 \\
\hline $\begin{array}{l}\text { T2 Shal } \\
\Delta \text { Storage }\end{array}$ & N/A & 15.43 & 12.53 & -39.20 & -52.40 & 10.02 & -1.05 & -30.05 & -24.55 & -2.25 & 88.71 \\
\hline
\end{tabular}

\section{Topography and Groundwater Flow}

Upon analyzing the LiDAR DEM, it appeared that the coastal morphology was made up of historic dune ridges, causing the rise and fall of the elevation in a uniform northwest direction perpendicular to the Atlantic Ocean. The LiDAR DEM showed that the northern edge of the study area (north well) maintained a fairly high elevation around 10-15 meters AMSL and the south side of the site reached elevations of 8 to 10 meters AMSL (Figure 20). The middle well is located at a lower elevation (7 meters AMSL) adjacent to an ephemeral stream that discharges into Big Bay Creek and on its upstream side, reaches northeast outside of the study site.

Groundwater flow paths were determined from the LiDAR DEM because water generally moves from high to low elevation areas. Therefore, it was deduced that a majority of the groundwater is flowing from the uplands into the lower elevation ephemeral stream and along the topographic break downslope from the uplands to the MTU. Figure 20 also

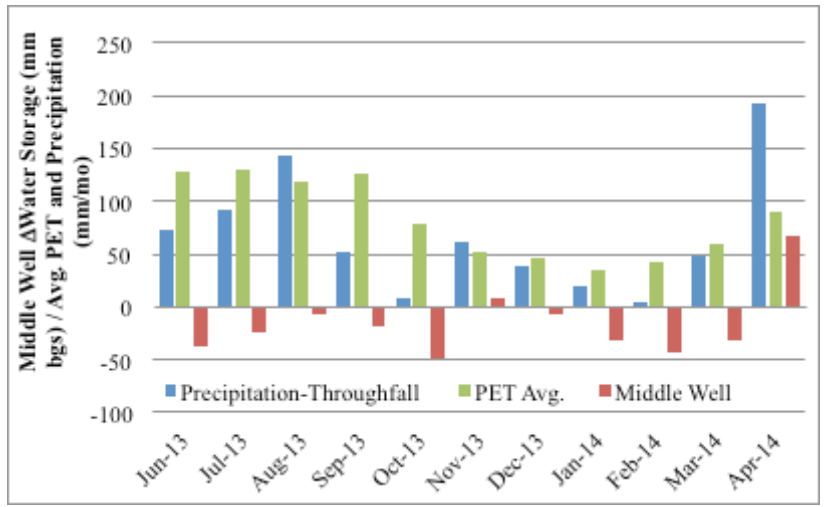

Figure 19. Monthly surplus/deficit of middle well over the study period. Negative: water deficit; positive: water surplus. shows that a portion of the groundwater flows away from the site, particularly along the northern watershed boundary.

The results from Darcy's Law calculations suggest that groundwater flow occurred at a faster rate from the south well to middle well as compared to the flow from the north well to the middle well. This is due to the slope of the hydraulic head across these sites. The groundwater flux from the south to middle well ranged from $1.48 \times 10^{4}$ to $3.75 \mathrm{~m} /$ day. The north

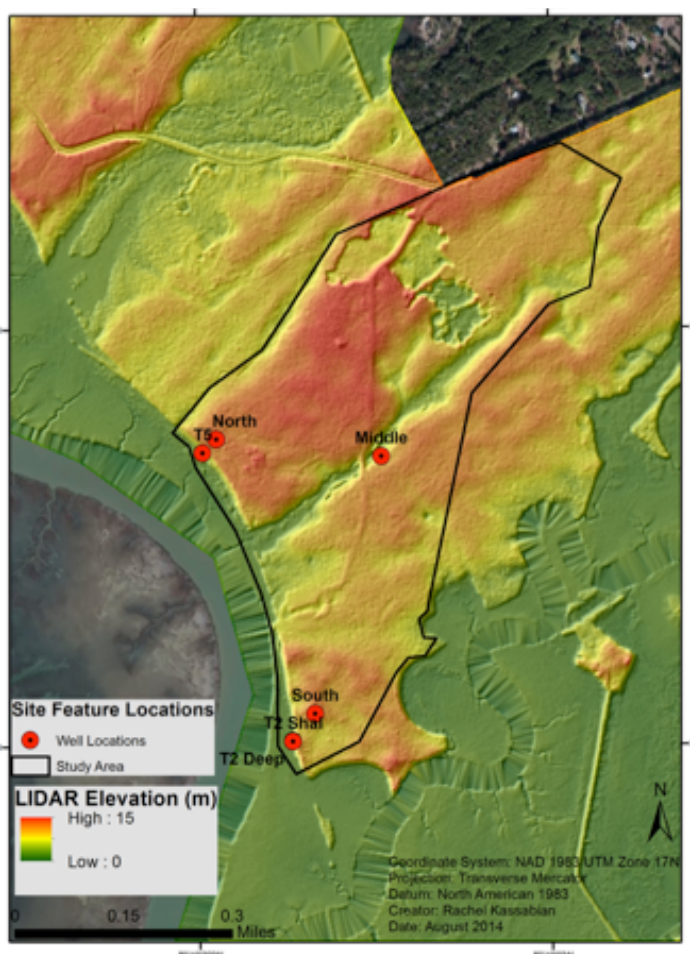

Figure 20. LiDAR digital elevation model (DEM) map of Edisto Beach State Park. Elevation is provided in meters above mean sea level. 
to middle groundwater flux ranged from $5.16 \times 10^{5}$ to $3.64 \mathrm{~m} /$ day. The differences in flow reflect differences in hydraulic conductivity $(\mathrm{K})$ and head value $(\Delta \mathrm{h})$.

\section{Soils and Vegetation}

Soil samples taken at each of the well sites were analyzed and classified by soil type. It was determined that the site is made up of fine-grained clean sand and loamy sand with a surface layer of organic material. There were also iron deposits found in depths reaching anoxic conditions on the north and south sides of the study site. The Natural Resources Conservation Service Web Soil Survey (n.d.) provided soil classifications that matched the general field classifications. The predominant soil type is Wando loamy fine sand $(\mathrm{WnB})$, making up $76 \%$ of the area of interest while Capers silty clay loam is present only in the ephemeral stream.

The basal area was calculated at each site and showed that the middle well $(0.30$ sq. meters $)$ and T5 marsh well ( 0.25 sq. meters) sites had the lowest basal area coverage. The north well ( 0.89 sq. meters) site had the greatest basal area coverage, followed by the south well ( 0.37 sq. meters) and the T2 marsh wells ( 0.35 sq. meters). Species dominance for each well site was also determined. The south well was dominated by two species of oak trees (Quercus falcata and Quercus nigra) making up 65\% of the basal area at the site. Loblolly pine trees (Pinus taeda) were the dominant species at the north well making up $90 \%$ of the basal area despite stem count dominance from oak trees. The middle well basal area was dominated by sabal palm trees (Sabal palmetto) that comprised $63 \%$ of the total basal area. Oak species (Quercus virginiana, Quercus laurifolia, and Quercus nigra) dominated the T5 well site's basal area coverage (78\%) despite stem count dominance of pine trees. The dominant species contributing to basal area coverage at the T2 wells was a sabal palm (Sabal palmetto) (42\%).

The basal area findings were dependent on the surrounding well locations measured out along the site. For this reason, sites that were located within a clearing or depression did not have as many trees to measure for basal area and therefore may not have been representative of their settings. For example, the marsh wells (T2 deep and shallow and T5) lacked measurable specimens for half of the site because of the well position along the uplandmarsh bank. The middle well location also limited the availability of measurable specimens due to its location in a sparse depression. It is apparent from these 200 sq. meter quandrants, which well sites have the greatest tree density immediately around the well site.

\section{CONCLUSION}

It was proposed that (A) groundwater level dynamics would mimic topography and salinity would decrease with increasing distance from Big Bay Creek; and (B) upland groundwater patterns would mimic evapotranspiration while the marsh groundwater patterns would reflect a tidal influence. The results of this study showed that other types of groundwater dynamics occur and are likely due to differences in environmental and topographic conditions across marsh-upland ecosystems. For example, groundwater patterns at the middle well (evapotranspiration dominance) and marsh well locations (tidal dominance) supported the hypothesis. However, the groundwater level at the south well was mainly influenced by tidal forcing patterns and not evapotranspiration patterns, despite the well being located at the highest elevation. This is likely due to its close proximity to the cut bank of Big Bay Creek. Therefore, proximity of the uplands to a tidal water body was shown to affect groundwater patterns more than elevation. The hypothesis that the upland groundwater will show a dominant evapotranspiration pattern did not stand regarding the south well. Alternatively, salinity levels at the north and south wells were related to the proximity of Big Bay Creek where groundwater was characterized as fresh, and at the marsh wells where groundwater was saline.

Additional evidence of alternative groundwater conditions showed that at the middle well, the highest salinity reading was recorded for the upland wells despite it being located furthest away from Big Bay Creek. The topography at the middle well may explain the uncharacteristic groundwater and salinity readings at this site. This well is located in a lower elevation slough which extends to the creek, and perhaps allows for surface water to enter into the slough. However, it was further questioned whether contamination affecting the salinity readings at the middle well occurred from the bentonite seal installation. The bentonite seal was applied around the same intersection of the middle well as the mean groundwater level. Previous studies found that contamination of groundwater from bentonite seals occur with a peak in contamination over the first 100 to 500 days of installation, as witnessed in the middle well hydrograph (Remenda and Kamp, 1997). Future research at this site may confirm this assumption through the installation and monitoring of a well at the slough-creek outlet. Beyond those findings, the hypothesis that groundwater would mimic topography was supported by the groundwater elevation graphs showing that the highest elevation locations also had the highest water table elevations AMSL.

The results of this study can be expanded to determine how sea level rise may affect the tidal salt marsh and upland habitats. In general, the lower elevation locations and those adjacent to the cut bank are at the greatest risk for future sea level rise. This can be seen in the northern high marsh (T5 well) where saltwater flooding events are already occurring (Figures 10 and 15). Despite these saltwater flooding events, the northern marsh acts as a net freshwater discharge area as evidenced by seasonal salinity variations at the T5 well which show lower salinity levels in the wet months (spring and summer) and higher salinity levels in the dry months (fall and winter). If saltwater intrusion continues into the upland north well, the amount of freshwater discharging would be diminished and could upset current marsh ecology.

Topographic variations at the site, as illuminated by the Lidar DEM (Figure 20), also indicate areas at risk for sea level rise. The topographic slope between the marsh 
and uplands determines marsh sediment accumulation and therefore the marsh's ability to retreat into the uplands in response to sea level rise. At this site, the topographic slope is gradual at the northern side and steep on the southern side. Therefore, despite current flooding occurring along the north MTU, the ability for the marsh sediment to accumulate and expand into the uplands is greater on the northern end of Edisto Beach State Park. Furthermore, dense Spartina alterniflora communities along the northern marsh will assist in sediment accumulation. Sediment accumulation at a rate greater than sea level rise will allow for the success of the marsh by retreating into the marsh-upland border.

MTU - upland areas with steeper slopes, such as the southern marsh, are at risk because areas of the MTU that are rarely flooded have slower vertical accretion rates since sediment is not constantly being deposited and settled out at the same rate as the lower marsh (Kirwan and Megonigal, 2013). Therefore, due to the higher elevation and infrequent flooding events, sediment may not accumulate at a rate that can keep up with sea level rise. In addition, the steep topographic gradient between the marsh and uplands at this site may make it difficult for the marsh to retreat into the uplands. This southern site is also at risk for saltwater intrusion as evidenced by the tidal signal apparent in the south upland groundwater hydrograph (Figure 3). This signal is believed to be a result of tidal forcing from Big Bay Creek. The geomorphology of the creek in the presence of the cut bank adjacent to the south end of the site allowed for propagation of tidal energy into the shallow freshwater aquifer. Therefore, the southern side of the marsh is clearly at risk for saltwater intrusion. This phenomenon is illustrated by the model of Schultz and Ruppel (2001) shown in Figure 21 in which the tidal signal loses amplitude as it migrates through the sediment further away from the creek. Saltwater intrusion from Big Bay Creek may also be occurring at the middle well although it is located furthest away from the creek. The middle well recorded high salinity levels and is adjacent to an ephemeral stream perhaps allowing saltwater from Big Bay Creek to enter into the uplands from this topographic low.

However, another groundwater input process may be simultaneously occurring as well. Groundwater from the uplands is likely flowing horizontally into the depression and recharging the middle well due to the decrease in elevation surrounding the middle well. This process was seen in the water budget following a rain event in mid-August when the groundwater of the north and south wells showed a water surplus at the end of the month and the middle well remained around the antecedent water level indicating discharge over the month (Figure 18). The location of the middle well as a discharge area and the north and south wells as recharge areas may explain the differences in water storage among the upland wells.

Additional groundwater trends that were revealed through the water budget analysis showed that the north and south upland wells did not differ much despite their distance. This may be due to their similar topographic and groundwater levels. The marsh wells generally followed similar water storage patterns although the T5 location had slightly greater water storage change. This may indicate that

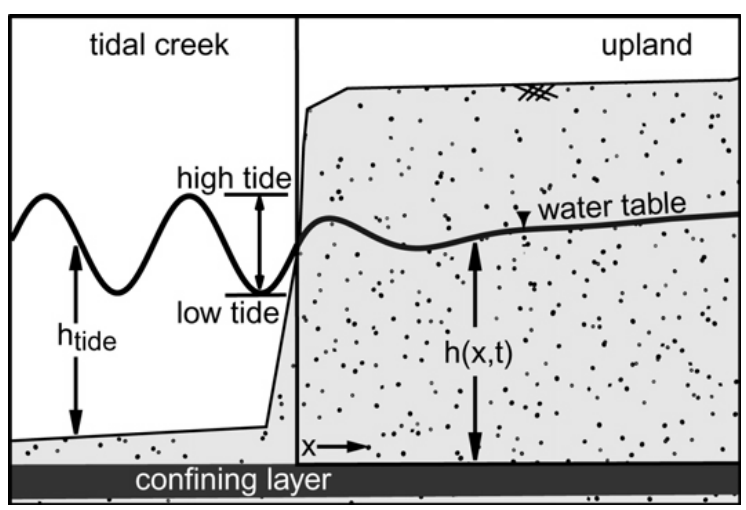

Figure 21. Diagram showing tidal flow pattern from the creek into the water table. The diagram shows the tidal amplitude lessening as it flows through the sediment (Schultz and Ruppel, 2001).

the groundwater at the $\mathrm{T} 5$ well recharges and discharges at a greater rate. A possible explanation may be that it is located along a high elevation togographic gradient in the MTU and that fresh groundwater may be discharging to the site while the creek may be recharging.

Further long-term investigation at the Edisto Beach State Park site may reveal areas of vulnerability to the fresh groundwater supply under the threat of saltwater intrusion and sea level rise. Coastal land managers may find this study useful in understanding the dynamics of similar saltmarshupland maritime forest ecosystems.

\section{LITERATURE CITED}

Amatya, D., R. Skaggs, G. Chescheir, and G. Fernandez, 2000. Solar and net radiation for estimating potential evaporation from three vegetation canopies. Presented at the July 2000 ASAE Annual International Meeting. Paper No. 002135. St. Joseph, Michigan, USA.

Dai, Z., C. Trettin, and D. Amatya, 2013. Effects of climate variability on forest hydrology and carbon sequestration on the Santee Experimental Forest in coastal South Carolina. United States Department of AgricultureForest Service. General Technical Report SRS-172.

Davis, S., 1969. Porosity and permeability of natural materials. Flow through Porous Media. Academic Press, New York, pg. 54-89. Fitts, C. (2013). Groundwater Science, (2nd ed.). Academic Press. Waltham, MA.

Doar, W. R., III, 2011. Fringe depositional units: A way of tracking the modern transgression through geologic mapping: Geological Society of America, Abstracts with Programs, p. 81.

Fitts, C., 2013. Groundwater Science (2nd ed.). Academic Press. Waltham, MA.

Freeze, R., and J. Cherry, 1979. Groundwater. Prentice Hall, Englewood Cliffs, NJ. 
Gardner, L. R., H. W. Reeves, and P. M. Thibodeau, 2002. Groundwater dynamics along forest-marsh transects in a southeastern salt Marsh, USA: Description, Interpretation and Challenges for Numerical Modeling. Wetlands Ecology and Management, 10, 145-159.

Harder, S. V., D. M. Amatya, T. J. Callahan, C. C. Trettin, and J. Hakkila, 2007. Hydrology and water budget for a first order forested Coastal Plain watershed, South Carolina. Journal of the American Water Resources Association 43(3), 563-575.

Helvey, J., and J. Patric, 1965. Canopy and litter interception by hardwoods of eastern United States. Water Resources Research, 1,193-206.

Kirwan, M., and P. Megonigal, 2013. Tidal wetland stability in the face of human impacts and sea-level rise. Nature, 304, 53-60.

Lu, J., G. Sun, S. McNulty, and D. Amatya, 2005. A comparison of six potential evapotranspiration methods for regional use in the southeastern United States. Journal of the American Water Resources Association, 41, pp. 621-633.

Mississippi Wildlife, Fisheries \& Parks (n.d.). Basal area: A guide for understanding the relationships between pine forests and wildlife habitat.

NOAA Ocean Service Education, 2008. Estuarine habitats - salt marshes. Accessed on March 16, 2014. Url: http:// oceanservice.noaa.gov/education/kits/estuaries/media/ supp_estuar06a_sal tmarsh.html

Natural Resources Conservation Service (NRCS) (n.d.). Official soil series descriptions. United States Department of Agriculture. Accessed on October 20, 2014. Url: http:// www.nrcs.usda.gov/wps/portal/nrcs/detailfull/soils/ home/?cid=nrcs 142p2 053587.

Park, A. Drennan, 1985. The Groundwater Resources of Charleston, Berkeley, and Dorchester Counties, South Carolina. Rep. No. SCWRC 139. South Carolina Department of Natural Resources.

Remenda, V., and G. Kamp, 1997. Contamination from sand-bentonite seal in monitoring wells installed in aquitards. Ground Water, 35 (1), 39-46.

Roth, F., and M. Chang, 1981. Throughfall in planted stands of four southern pine species in east Texas. Water Resources Bulletin, 17, 880-885.

Schultz, D., C. Ruppel, 2001. Constraints on hydraulic parameters and implications for groundwater flux across the upland-estuary interface. Journal of Hydrology, 260, 255-269.

Solinst, 2013. User Guide: Levelogger Series - Software

Version 4. Solinst Canada LTD.

South Carolina Department of Natural Resources (SCDNR), 2009. South Carolina's Water Resources. South Carolina State Water Assessment, 2nd ed. Columbia, SC. Ch. 3, pg. 1-46.

Walsh, R., 2010. Basal Area Guide. Mississippi Wildlife, Fisheries, and Parks, vol. 1-2.

Wenner, E., 2010. Dynamics of the Salt Marsh- An Information/Education Series from the Marine Resources Division. South Carolina Department of Natural Resources.
Whitaker, J., J. McCord, B. Pulley and E. Mullins, E, (2009). Best Management Practices for Wildlife in Maritime Forest Developments. South Carolina Department of Natural Resources. Url: http://www.dnr. sc.gov/marine/pub/BMPSforCoastWeb.pdf 